Article

\title{
Developing and Implementing Climate Change Adaptation Options in Forest Ecosystems: A Case Study in Southwestern Oregon, USA
}

\author{
Jessica E. Halofsky ${ }^{1, *}$, David L. Peterson ${ }^{2}$, Kerry L. Metlen ${ }^{3}$, M. Gwyneth Myer ${ }^{4}$ \\ and V. Alaric Sample ${ }^{5}$ \\ 1 School of Environmental and Forest Sciences, University of Washington, Box 352100, Seattle, WA 98195, \\ USA; jhalo@uw.edu \\ 2 U.S. Forest Service, Pacific Northwest Research Station, 400 N. 34th Street, Seattle, WA 98103, USA; \\ peterson@fs.fed.us \\ 3 The Nature Conservancy, 33 North Central Ave, Suite 405, Medford, OR 97501-5939, USA; kmetlen@tnc.org \\ 4 Southern Oregon Forest Restoration Collaborative, 13401 Highway 66, Ashland, OR 97520, USA; \\ gwynmyer@gmail.com \\ 5 Pinchot Institute for Conservation, 1400 16th Street Northwest, Suite 350, Washington, DC 20036, USA; \\ alsample@pinchot.org \\ * Correspondence: jhalo@uw.edu; Tel.: +1-206-543-9138
}

Academic Editors: Carl Beierkuhnlein and Andreas Bolte

Received: 1 September 2016; Accepted: 2 November 2016; Published: 7 November 2016

\begin{abstract}
Climate change will likely have significant effects on forest ecosystems worldwide. In Mediterranean regions, such as that in southwestern Oregon, USA, changes will likely be driven mainly by wildfire and drought. To minimize the negative effects of climate change, resource managers require tools and information to assess climate change vulnerabilities and to develop and implement adaptation actions. We developed an approach to facilitate development and implementation of climate change adaptation options in forest management. This approach, applied in a southwestern Oregon study region, involved establishment of a science-manager partnership, a science-based assessment of forest and woodland vulnerabilities to climate change, climate change education in multiple formats, hands-on development of adaptation options, and application of tools to incorporate climate change in planned projects. Through this approach, we improved local manager understanding of the potential effects of climate change in southwestern Oregon, and enabled evaluation of proposed management activities in the context of climatic stressors. Engaging managers throughout the project increased ownership of the process and outcomes, as well as the applicability of the adaptation options to on-the-ground actions. Science-management partnerships can effectively incorporate evolving science, regardless of the socio-political environment, and facilitate timely progress in adaptation to climate change.
\end{abstract}

Keywords: adaptation; climate change; resource management; vegetation; vulnerability assessment; southwestern Oregon; Klamath-Siskiyou ecoregion

\section{Introduction}

Climate change poses significant challenges to the sustainable management of forest ecosystems in the United States. With warming temperatures over the last few decades, changes in physical and ecological processes are already becoming apparent. For example, there have been declines in snowfall in many parts of the country [1]. In the western U.S., there have been declines in snowpack [2], mountain precipitation [3], and streamflows [4]. Drought severity has increased in several regions [5,6]. The area affected by disturbances, such as insect outbreaks [7,8] and wildfire [9], has also increased. 
These trends of increasing temperatures, changing precipitation patterns, and increasing extreme events such as drought and fire are expected to continue in this century, driving changes in forest ecosystems $[10,11]$.

Adapting to climate change, or "the process of adjustment to actual or expected climate and its effects" [12], is critical to minimize the risks associated with climate change impacts. Significant progress has been made in climate change adaptation in the U.S. in recent years, in multiple sectors, levels of government, and in the private sector [13-15]. At the federal level, adaptation planning has been spurred by President Obama's Executive Order 13514 [16], which requires federal agencies to evaluate climate change risks and vulnerabilities and develop climate adaptation plans, and by Executive Order 13653 [17], which requires federal agencies to complete an inventory and assessment of (proposed or completed) changes in their policies, programs, and regulations that would help make ecosystems and the people that depend on them more resilient to climate change.

Along with increasing recognition of the importance of addressing climate change, these Executive-level orders have spurred increased climate change activity in federal natural resource management agencies over the last few years. This activity has led to a variety of assessments, strategies, guiding documents, and new agency positions and organizations focused on climate change. Currently, most federal agencies have broad-scale strategic plans that describe approaches and priorities for climate change in general, and for adaptation in particular, and several departments and agencies have built on initial strategic documents to increase capacity and develop more detailed plans for assessing vulnerabilities and adapting management to climate change [14]. For example, the U.S. Forest Service has a national climate change office, a roadmap that guides response to climate change, a scorecard that tracks accomplishments in ten areas, and climate change coordinators at the regional and national forest levels. Supplemented by scientific information from its research and development branch, the Forest Service is progressively developing vulnerability assessments and adaptation plans throughout the United States. Similarly, the National Park Service has a national climate change office, a climate change response strategy, and a staff that conducts scenario planning and other activities in national parks. Much of the progress in climate change adaptation in natural resource management to date has been accomplished through collaboration between scientists and resource managers [14,15,18-21].

Although nearly all federal natural resource management agencies have an overarching response strategy for adaptation, and in some cases a framework for doing so, accountability for developing and implementing adaptation options has been minimal among federal agencies [14]. Field units are rarely required to assess the vulnerability of resources to climate change or develop and implement adaptation responses. Many land managers would like to develop vulnerability assessments and adaptation plans at the field-unit scale, but in the absence of a mandate, sufficient budgets, and accountability for implementation, progress has been impeded.

Here, we describe an approach to facilitate development and implementation of climate change adaptation options in forest management. Our approach builds on that developed previous work [21,22], but it is relatively unique in the climate change vulnerability assessment and adaptation literature in its focus on facilitating implementation of adaptation options at the project level. The approach (adapted from [21]) relied heavily on participation of local specialists across multiple organizations to establish a science-manager partnership, develop climate change education in multiple formats, facilitate hands-on development of adaptation options, and convene a hands-on application of tools to incorporate climate change in planned projects and prioritize future projects under a changing climate. We specifically describe the application of the approach and outcomes in a southwestern Oregon, USA study region, a region known for both high ecological diversity and complex natural resource management issues [23]. Finally, we evaluate the effectiveness of the approach and suggest next steps to facilitate implementation of climate change adaptation actions. 


\section{Materials and Methods}

\subsection{Study Area}

The study region (1.9 million hectares; Figure 1) encompasses the Rogue Basin in the southwestern corner of Oregon, USA. The study region includes forest lands managed by the U.S. Forest Service (736,000 hectares) and Bureau of Land Management (BLM) (371,000 hectares). Home to many endemic plant species, the Rogue Basin has the highest vegetative diversity in the Pacific Northwest region. The Rogue Basin includes portions of the Klamath-Siskiyou Ecoregion, one of seven International Union for Conservation of Nature areas of global botanical significance in North America [24]. Diverse floras from several western U.S. floristic provinces intermingle in the complex environmental and geomorphological gradients that characterize the landscape. These complex gradients have allowed for persistence of localized climatic conditions, or climate refugia, amid broader climatic changes in the past. In dry forests and woodlands of the northern Klamath Mountains and southern slopes of the Cascades, steep topographic gradients and a strong Mediterranean climate historically drove frequent fire regimes with mixed severity effects [23,25-27]. Dry forest types in the analysis area are largely dominated by native Douglas-fir (Pseudotsuga menziesii (Mirb.) Franco), but include types dominated by other native species such as white fir (Abies concolor (Gordon \& Glend.) Lindl. ex Hildebr.), Jeffery pine (Pinus jeffreyi Grev. \& Balf.), ponderosa pine (Pinus ponderosa Douglas ex P. Lawson \& C. Lawson), and tanoak (Notholithocarpus densiflorus (Hook. \& Arn.) Reh.). Native oak woodlands, comprised largely of tanoak with California black oak, increase in abundance in the mountains away from the coast, and Oregon white oak is abundant in the inland valleys.

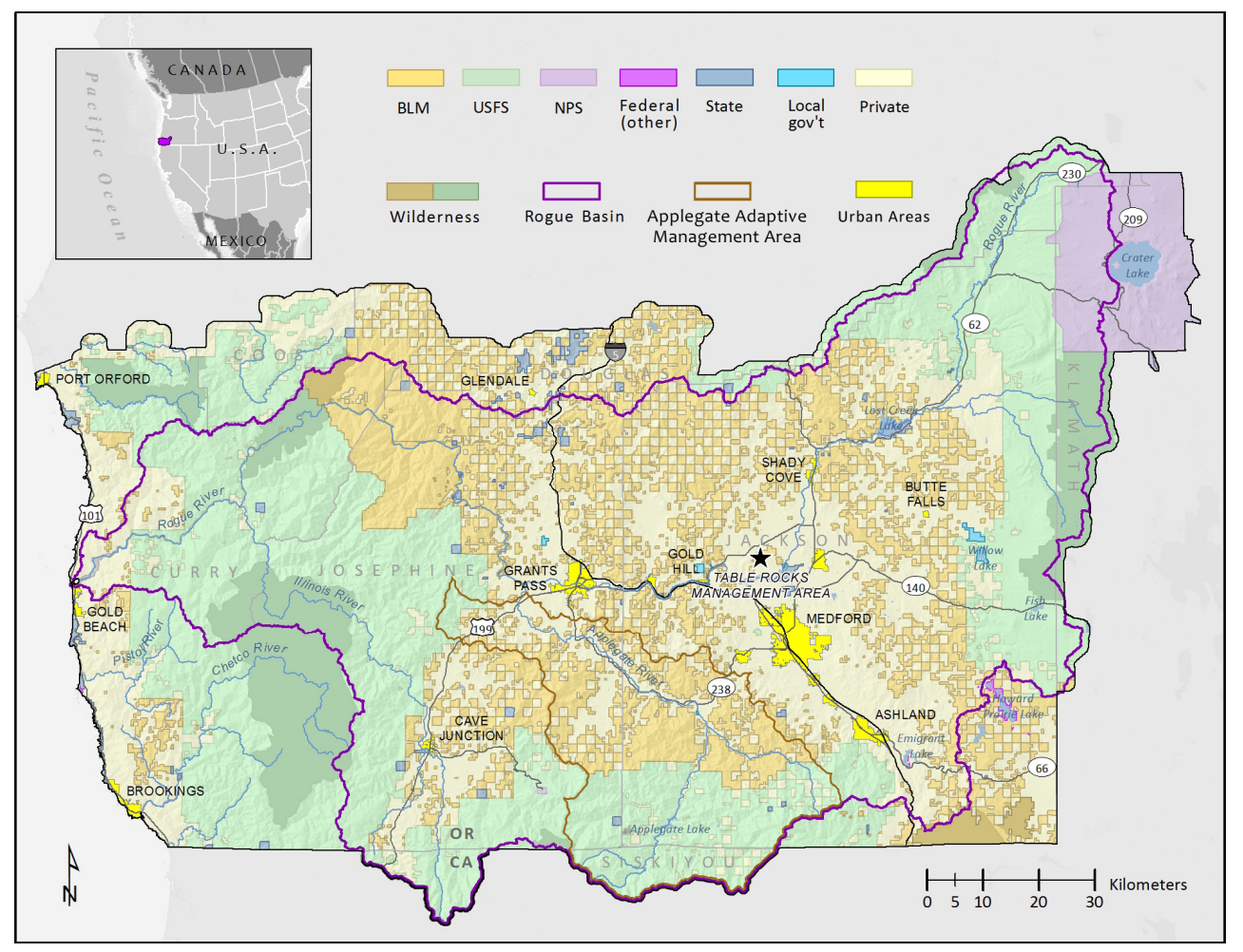

Figure 1. Study area location and land management/ownership in southwestern Oregon, USA. Federal land management agencies include the Bureau of Land Management (BLM), the U.S. Forest Service (USFS), and the National Park Service (NPS). The Applegate Adaptive Management Area and Table Rocks Management Area, focus areas in our effort, are identified. Map by A. Jones, the Nature Conservancy. 
Globally, Mediterranean forests and woodlands are of high conservation importance due to habitat conversion and lack of protection [28]. Fire regimes have been significantly disrupted for the last 100 years across the Mediterranean forests and woodlands of the Rogue Basin [29-32], including lowland and mixed conifer riparian forests [33]. Wildfire exclusion, combined with extensive even-aged timber management and other land uses, has resulted in forests at risk to wildfire, insects, and disease, issues exacerbated by climate change [32,34-36]. These risks threaten complex forests habitats, the oldest most structurally important trees, and even the re-establishment and development of younger stands [35].

\subsection{Development of a Science-Manager Partnership}

The first step in our process was to develop a partnership among scientists and local natural resource managers and specialists. We chose to build on a project led by the Southern Oregon Forest Restoration Collaborative (SOFRC) that resulted in a climate change action plan for watersheds and forests in the Rogue River Basin in southwestern Oregon [37]. The SOFRC work provided a preexisting science-management partnership, which included U.S. Forest Service and BLM line officers, planners, and resource specialists, scientists from The Nature Conservancy, and others. We initially convened representatives from each agency/organization on conference calls to establish project scope, focal resources, timeline, and communication plan. These calls continued on a monthly to bi-monthly basis as the project developed, with substantial engagement from the local partners. A broader and more diverse group of participants was selected to participate in the webinars and workshop (see Sections 2.4 and 2.5).

\subsection{Vulnerability Assessment of Forest Resources to Climate Change}

The next step in the process was to gather existing information to assess the vulnerability of forest resources in the Rogue Basin to climate change. Vulnerability assessments address "the propensity or predisposition [of a system] to be adversely affected" [12], and are necessary to inform adaptation planning and reduce the negative consequences of climate change. The assessment considered the sensitivity (susceptibility to harm) and adaptive capacity (capacity to cope and adapt) [12] for forest vegetation in the Rogue Basin. We also assessed potential exposure to climate change, a component of risk [12].

To assess potential sensitivity of vegetation, we built on [37] and considered relevant paleoecological studies of climate and species distribution, as well as studies reporting trends in tree growth and species composition with recent climate change. Available vegetation and fire model projections, including those from empirical and process-based models, were also considered. More than simple literature reviews, the sensitivity assessments involved evaluation of the quality and relevance of the science for the vegetation types of the region. To assess potential adaptive capacity of ecosystems in southwestern Oregon, we also utilized spatial information from [38] identifying landscape locations likely to be resilient to climatic changes, based on geophysical diversity and landscape permeability to migration (sensu [39]). To assess exposure, we used global climate model projections in the U.S. National Climate Assessment [40].

\subsection{Communication of Climate Change Information}

To communicate information from the climate change vulnerability assessment, we developed and delivered an engagement strategy for local managers that included a series of five webinars, building to a one-day hands-on workshop and a field trip to facilitate applied adaptation planning. The webinars included climate projections for the Rogue Basin and an overview of forest vegetation vulnerabilities to climate change. We provided information on an assessment of adaptive capacity of ecosystems in the region [39] and its incorporation in a framework for prioritizing restoration work in southwestern Oregon under changing climate [41]. The webinars also covered potential effects of 
climate change on hydrology, aquatic organisms, and terrestrial wildlife, topics of interest to the local resource managers.

\subsection{Hands-On Development of Adaptation Options}

The webinars provided a base of information that we reviewed in the first half of a one-day workshop, allowing ample opportunity for questions, open discussion, and feedback on the vulnerability assessment. The workshop was attended by over 40 participants, comprised of approximately $50 \%$ Forest Service, $40 \%$ BLM, and $10 \%$ university and other organizations. The second portion of the workshop was used to develop adaptation options in small working groups. This exercise focused on a planned project and modifications or additional activities that could be added with an explicit climate change consideration. We chose this approach to illustrate how climate change information can be applied to on-the-ground management actions and to facilitate implementation of climate-informed practices in the region. This approach built on a process honed in previous climate change adaptation workshops conducted across the western U.S. over the last decade [19-21].

The project that was evaluated in the workshop is located in the Applegate Adaptive Management Area (AMA) (Figures 1 and 2), a joint Forest Service and BLM-managed watershed, focused on the Upper Applegate planning area. A federal project team had developed goals, objectives, and general project activities prior to the workshop. Team members from the project team were present to answer questions and provide information about the project and project area. We used a modified version of the Climate Project Screening Tool [42], originally developed by Forest Service staff for a similar purpose, to aid participants in evaluating project activity outcomes under a changing climate. Each small (3-10 person) working group answered the following questions about project goals and proposed activities and reported on the outcomes (see Section 3):

1. Are there any challenges to meeting the goals/objectives because of climate change?

2. How may the project activity need to be revised when considering impacts from climate change (e.g., consider spatial scale, temporal scale, features)?

3. How do the new or revised approaches compare in effectiveness and feasibility to the proposed activity and accompanying goals?

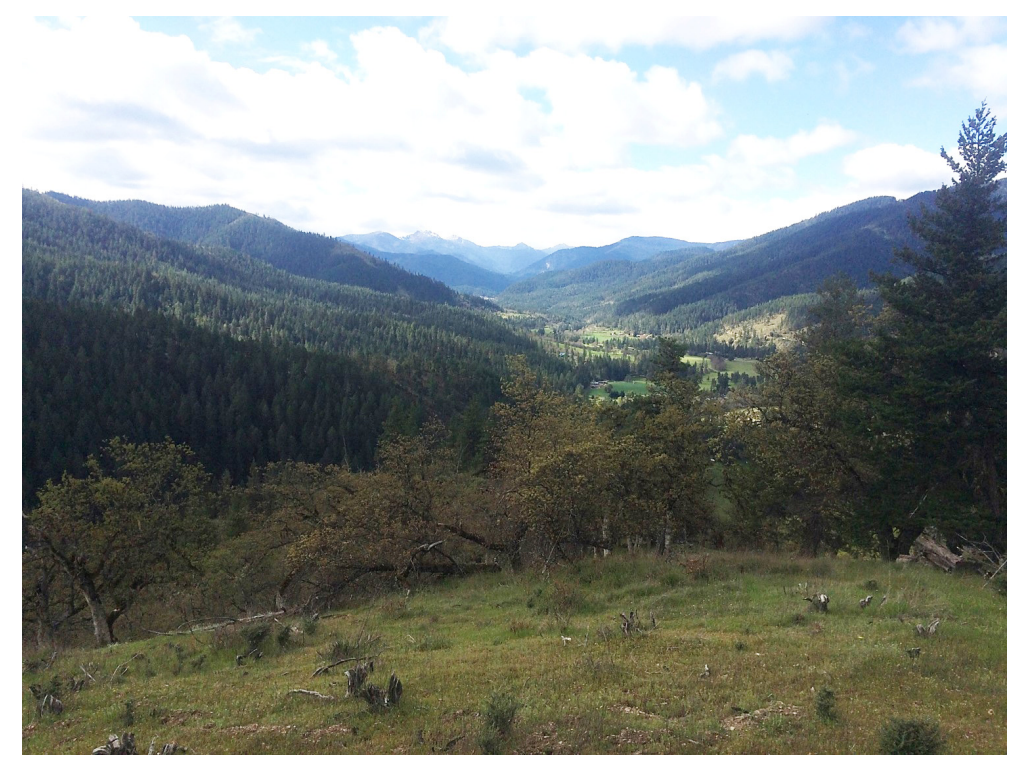

Figure 2. View of the Applegate Adaptive Management Area. Planned project activities for this area were evaluated based on projected climate change impacts in southwestern Oregon. Photo by D. Boucher, U.S. Forest Service. 


\subsection{Field Trip Illustrating Climate-Informed Management Actions}

To further illustrate how an on-the-ground project could incorporate climate change, the workshop was followed by a half-day field trip to the Table Rocks oak restoration project area (Figure 1). This joint project included several agencies and non-governmental organizations working to reintroduce characteristic fire to increase future resistance and resilience of oak woodlands. The field trip leaders gave an overview of the process and planning behind the Table Rocks project. Local scientists described how climate change was considered in the project using future white oak habitat projections from [43] and a forest restoration prioritization framework developed for the region [41], which focused on promoting landscape resilience, mitigating wildfire risk, protecting and promoting complex forest in sustainable landscape settings, and concentrating conservation efforts on climate resilient landscape facets. This information provided a climate adaptation framework for planning, sensu [44]. Building on this framework, non-governmental organization and agency collaborators successfully attained funding from government and non-governmental sources for actions on agency and private land, and they are currently implementing treatments, with multiparty monitoring driving adaptive management.

\section{Results}

\subsection{Potential Climate Change Effects on Forest Ecosystems in the Rogue Basin}

In the Rogue Basin, increased annual temperatures and seasonal precipitation shifts will likely result in increased summer moisture stress for forest and woodland ecosystems. Average annual temperatures in the region are likely to rise by approximately $1.8^{\circ} \mathrm{C}$ to $5.4{ }^{\circ} \mathrm{C}$ by the end of the century, and summer precipitation may decrease by as much as $30 \%$ by the end of the century [40]. Summer water deficit and drought severity will likely increase because of increased temperatures and lower precipitation in summer [45,46]. Reduced snowpack and earlier peak stream flows, along with the potential for more extreme precipitation events, will increase flood risk in winter and early spring [47,48], and result in lower summer stream flows [48,49]. Wildfire risk will also increase with increasing temperatures and earlier snowmelt $[9,46,50,51]$.

The diverse biota of the serpentine soils of the Siskiyou Mountains have been stable over millennia, even as other vegetation types have shifted [52]. However, rapidly changing climate and land management effects have been correlated with significant shifts in the herbaceous communities of the Siskiyous from 1950 to 2008 [53,54], suggesting that species with narrow ecological amplitude may be at risk. Documented compositional changes reflect adaptation to a warmer climate, with reduced cover of species with northerly biogeographic origin, reduction in specific leaf area, and an increasing proportion of the community comprised of dry habitat species [53,54].

Modeling projections for future vegetation communities suggest that grasslands, chaparral, and montane forests are likely to expand, while alpine and subalpine forest cover is expected to contract under climate change [50,55-57] (Table 1). The process-based MC1 model suggests that coastal coniferous forests of the Rogue Basin may transition to more hardwood-dominated subtropical forests with decreases in frost [50,56], and that montane coniferous forests could transition to more xeric evergreen forest and oak woodland [56,57]. Oak woodlands and prairie ecosystems of the Pacific Northwest may be well-suited to future climate [43,58,59] (Table 2), although they will likely be affected indirectly by other factors, such as high-severity fire and invasive species [60]. Tree growth will likely decrease for many species with increasing summer drought stress [61]. Drought stress can increase host tree vulnerability to insects and disease [45], and combined with elevated temperatures, may drive tree mortality [62].

Climate change is projected to increase the likelihood of wildfire [9,50,51], fire severity on conifers $[50,63,64]$, and suppression difficulty [65] across western North America. Severe fires release more carbon than fires of lower intensity [66-68], and can turn forests into net carbon sources for years to decades [67,69], although this is not always the case [70]. In the Mediterranean forests and 
woodlands of the Rogue Basin, the likelihood of very large fire is expected to increase, possibly by $300 \%-500 \%$ by 2070 [51], shifting the conversation from if fires will burn to how they will burn. Increased incidence of large, severe fires will likely affect ability of forest ecosystems to provide ecosystem services, including carbon storage [50], water quality, wildlife habitat, and recreation opportunities [11].

Large, high severity patches can fail to regenerate with conifers because of long distances to seed sources [71,72], harsh environmental conditions, and competition from other vegetation [25,72]. Lack of regeneration can be exacerbated by future fires, where severe fire patches have been shown to promulgate severe fire patches in subsequent fires, effectively reinforcing the tendency to move from forest to shrub or grassland [73,74]. Long-term conversion of forest to other vegetation types can compromise sequestration of carbon and alter wildlife habitat attributes [11], exacerbating climate change impacts described above.

Table 1. Summary of vulnerability of vegetation types in the Rogue Basin in southwestern Oregon, as determined by the climate change vulnerability assessment described above. Vegetation types with high vulnerability to climate change are likely to contract significantly or may experience extensive mortality in the future, whereas vegetation types with low vulnerability to climate change are likely to maintain current area or increase in area (although their distribution across the landscape may shift). Composition of all vegetation types is likely to shift to more drought and fire tolerant species. Late-successional forest structures, such as snags and down wood, will be vulnerable to fire.

\begin{tabular}{|c|c|c|}
\hline Vegetation Type & Potential Climate Change Impacts & $\begin{array}{l}\text { Vulnerability to } \\
\text { Climate Change }\end{array}$ \\
\hline Alpine vegetation & $\begin{array}{l}\text { More precipitation falling as rain rather than snow [40]; } \\
\text { earlier snowmelt [40]; lower snowpacks [3]; longer } \\
\text { growing seasons [40]; contraction of climatically-suitable } \\
\text { habitat for alpine vegetation }[50,56,57]\end{array}$ & High \\
\hline Subalpine forests & $\begin{array}{l}\text { More precipitation falling as rain rather than snow [40]; } \\
\text { earlier snowmelt [40]; lower snowpacks [3]; longer } \\
\text { growing seasons; possible increases in fire and } \\
\text { drought }[75,76] \text {; contraction of climatically-suitable } \\
\text { habitat for subalpine vegetation }[50,56,57]\end{array}$ & High \\
\hline Montane forests & $\begin{array}{l}\text { Lower snowpacks [3]; longer growing seasons [40]; } \\
\text { increased area burned and burn severity }[50,51] ; \\
\text { increased summer water stress and drought } \\
\text { severity }[45,46] ; \text { shifts to more xeric evergreen forest and } \\
\text { oak woodland vegetation }[56,57]\end{array}$ & Moderate \\
\hline Dry forests & $\begin{array}{l}\text { Increased area burned and burn severity }[50,51] \text {; } \\
\text { increased summer water stress and drought } \\
\text { severity }[45,46] \text {; potential for increased post-disturbance } \\
\text { regeneration failures [11]; shifts to more xeric evergreen } \\
\text { forest and oak woodland vegetation }[56,57]\end{array}$ & High \\
\hline Oak woodlands & $\begin{array}{l}\text { Increased area burned and burn severity }[50,51] \\
\text { increased summer water stress and drought } \\
\text { severity }[45,46] \text {, invasive non-native annual grasses [60] }\end{array}$ & Moderate \\
\hline Chaparral & $\begin{array}{l}\text { Increased area burned }[50,51] \text {; increased summer water } \\
\text { stress and drought severity }[45,46]\end{array}$ & Low \\
\hline Grasslands & $\begin{array}{l}\text { Increased area burned }[50,51] \text {; increased summer water } \\
\text { stress and drought severity }[45,46] \text {, invasive non-native } \\
\text { annual grasses [60] }\end{array}$ & Low \\
\hline
\end{tabular}

\subsection{Adaptation Options for the Applegate Adaptive Management Area}

In a drought-prone and fire-prone region such as southwestern Oregon, reducing stand density and reintroducing characteristic low and mixed severity fire are primary actions for increasing forest resilience to climate change. Reducing stand density with thinning can increase water availability 
and tree growth and vigor by reducing competition [77]. Decreases in forest stand density, coupled with hazardous fuels treatment, can also increase forest resilience to wildfire [34-36]. Managers at our adaptation workshop suggested increasing the amount of thinning planned in the Applegate AMA, and they also suggested altering thinning prescriptions and placement (Table 2). For example, forest thinning prescriptions may need to further reduce forest density and increase gap sizes to provide for establishment and growing conditions for desired drought and fire tolerant tree, shrub, and herbaceous species. Thinning treatments could also be prioritized in locations where climate change effects, particularly increased summer drought, are expected to be most pronounced, in high-value habitats (e.g., riparian zones) and in high-risk locations such as the wildland-urban interface (Table 2). Managers also suggested that prescribed burning be used more frequently to mimic effects of wildfire in reducing stand density and fuels, thus increasing the likelihood of favorable outcomes when subsequent wildfires occur.

Increasing fire will put forest legacy structures, such as large, old trees, snags and downed wood, at risk. Legacy structures have disproportionate habitat value for a large number of species. Managers in southwestern Oregon suggested that legacy structures be protected from fire by thinning around them and reducing duff build-up at the base of legacy trees (Table 2). To improve wildlife habitat, thinned and fire-killed trees can be left as structure rather than being removed. Increasing the density of legacy structures may be particularly effective in younger forests near late-successional forest to increase habitat quality and connectivity.

Many plant species will be subjected to increasing stress in a changing climate, and some species and genotypes may be unable to adapt to rapid warming. Similarly, areas with low species and genetic diversity will likely be more susceptible to the stressors associated with climate change. Genetic stock that is better adapted to climatic conditions of the future will be more resilient and increase overall ecosystem resilience. Thus, managers suggested planting species and genotypes that will be better adapted to future conditions (Table 2). Promoting species and genetic diversity, through plantings and in thinning treatments, will likely increase forest resilience to changing climate [78]. Promoting landscape heterogeneity in terms of diverse species and stand structures across a landscape mosaic may also help to decrease size and severity of wildfire, and insect and disease outbreaks.

Reducing the effects of existing non-climatic stressors on ecosystems, such as landscape fragmentation and invasive species, will likely increase ecosystem resilience to climatic changes [79]. Early detection, rapid response was suggested to prevent invasive species establishment. In particular, treatment of species that have the potential to delay development of desired vegetation structure can be prioritized.

There are significant uncertainties associated with future conditions under changing climate, and managers in southwestern Oregon recognized the critical role that learning through experimentation and monitoring will play in coping with future uncertainty. They suggested experimentation with thinning prescriptions, and potentially conducting treatments in locations such as riparian areas where thinning is not permitted under current policy. Monitoring will also be critical in detecting changes in plant species regeneration, growth, and mortality with changing climate and to determine treatment effectiveness under climate change [79]. For example, tracking tree species regeneration and distribution will help managers determine how species are responding to climatic changes and how to adjust management accordingly (e.g., guidelines for planting). Managers did not suggest any revision to underlying goals and objectives, though it should be acknowledged that the goals and objectives were general and mainly focused on restoring habitat structure and function, and thus consistent with goals to increase resilience to climate change. 
Table 2. Revisions to the Applegate Adaptive Management Area restoration project activities, suggested by managers after considering climate change.

\begin{tabular}{|c|c|c|c|c|}
\hline Project Objectives & Project Activity & $\begin{array}{l}\text { Challenges to Meeting Goals/Objectives } \\
\text { Because of Climate Change }\end{array}$ & Suggested Revision to Project Activity & $\begin{array}{l}\text { Potential Effectiveness and } \\
\text { Feasibility of the Revised Activity }\end{array}$ \\
\hline \multirow[t]{2}{*}{$\begin{array}{l}\text { Restore plantations to more } \\
\text { resilient conditions }\end{array}$} & Noncommercial thinning & $\begin{array}{l}\text { Plantation stock may not be well-adapted to } \\
\text { future climate, and there may be decreased } \\
\text { resistance to certain insects and disease. }\end{array}$ & $\begin{array}{l}\text { Create gaps, and reduce planting density to reduce } \\
\text { moisture stress; plant diverse genotypes and } \\
\text { species that may be better adapted to future } \\
\text { conditions; use fire instead of mechanical thinning } \\
\text { when possible to reduce future fire risk. }\end{array}$ & $\begin{array}{l}\text { Revised treatments may be more } \\
\text { expensive, but they will likely } \\
\text { decrease risk of fire and insect and } \\
\text { disease outbreaks. }\end{array}$ \\
\hline & Commercial thinning & Increased moisture stress and fire risk. & $\begin{array}{l}\text { Target plantations that might threaten more } \\
\text { resilient areas; use radial/donut thinning around } \\
\text { pines; assess past management practices to } \\
\text { determine priorities for treatment. }\end{array}$ & $\begin{array}{l}\text { Without long-term maintenance, } \\
\text { there is uncertainty about whether } \\
\text { thinning treatments will be useful } \\
\text { over the long term. }\end{array}$ \\
\hline $\begin{array}{l}\text { Reduce risk to communities } \\
\text { and other developed areas } \\
\text { from uncharacteristic } \\
\text { wildland fire }\end{array}$ & Non-commercial thinning & Increased fire risk. & $\begin{array}{l}\text { Increase thinning activities in the } \\
\text { wildland-urban interface. }\end{array}$ & $\begin{array}{l}\text { Budget is extremely limited and } \\
\text { treatments need to be maintained to } \\
\text { be remain effective. }\end{array}$ \\
\hline $\begin{array}{l}\text { Mitigate natural stand } \\
\text { conditions that contribute to } \\
\text { insect and disease outbreaks }\end{array}$ & $\begin{array}{l}\text { Commercial and } \\
\text { noncommercial thinning }\end{array}$ & $\begin{array}{l}\text { Increased insect and disease outbreaks, } \\
\text { particularly in overstocked stands. }\end{array}$ & $\begin{array}{l}\text { Increase thinning and prescribed fire activities; } \\
\text { target older, mid-to closed-canopy stands; target } \\
\text { pine-oak woodlands and remove shade } \\
\text { tolerant species. }\end{array}$ & $\begin{array}{l}\text { It is difficult to treat a sufficient area } \\
\text { to have an impact at the } \\
\text { landscape scale; windows for } \\
\text { prescribed burning are small, and } \\
\text { tolerance for smoke is low. }\end{array}$ \\
\hline \multirow{2}{*}{$\begin{array}{l}\text { Develop and maintain } \\
\text { complex forest habitats } \\
\text { for wildlife }\end{array}$} & $\begin{array}{l}\text { Strategic placement of habitat } \\
\text { development treatments }\end{array}$ & Increased fire risk and vegetation type shifts. & $\begin{array}{l}\text { Develop habitat where it is resistant to the effects } \\
\text { of climate change (e.g., oak woodlands will likely } \\
\text { be more resistant than Douglas-fir stands); create } \\
\text { redundancies in habitat across the landscape; } \\
\text { create habitat connectivity. }\end{array}$ & \\
\hline & Legacy tree retention & $\begin{array}{l}\text { Increased fire risk with climate change, and } \\
\text { increased risk of loss of legacy structures. }\end{array}$ & $\begin{array}{l}\text { Favor certain species depending on aspect (e.g., } \\
\text { more drought-tolerant pine or oak on warmer } \\
\text { south-facing slopes); select higher vigor trees for } \\
\text { retention; thin around legacy trees and remove } \\
\text { duff from around the base. }\end{array}$ & $\begin{array}{l}\text { Revisions will require more time in } \\
\text { selecting trees for retention, and they } \\
\text { will increase costs; designing logging } \\
\text { systems will be more complicated. }\end{array}$ \\
\hline Treat non-native plants & $\begin{array}{l}\text { Increase resistance to } \\
\text { non-native plant invasion }\end{array}$ & $\begin{array}{l}\text { Vegetation shifts and potential for } \\
\text { disturbance to increase risk of invasion. }\end{array}$ & $\begin{array}{l}\text { Seed native species and use locally-sourced seed; } \\
\text { reduce impacts of treatments on existing native } \\
\text { species; use early detection/rapid response } \\
\text { for non-natives. }\end{array}$ & $\begin{array}{l}\text { May need to develop new treatments } \\
\text { for non-natives (e.g., different } \\
\text { herbicides); monitoring will need to } \\
\text { be increased. }\end{array}$ \\
\hline \multirow{2}{*}{$\begin{array}{l}\text { Maintain watershed health } \\
\text { (water quality, fish habitat, } \\
\text { and site productivity) }\end{array}$} & Increase forest canopy cover & $\begin{array}{l}\text { Increased fire risk in riparian areas with less } \\
\text { summer precipitation and lower summer } \\
\text { stream flows. }\end{array}$ & $\begin{array}{l}\text { Allow thinning in riparian areas to increase tree } \\
\text { size and function. }\end{array}$ & $\begin{array}{l}\text { Need to design thinning treatments } \\
\text { that have "no effect" for water quality } \\
\text { and water temperature. }\end{array}$ \\
\hline & Planting native vegetation & $\begin{array}{l}\text { Increased summer drought stress and risk of } \\
\text { mortality in planted vegetation. }\end{array}$ & $\begin{array}{l}\text { Increase diversity of shrubs and trees to provide } \\
\text { functions (shade, water storage) that may help } \\
\text { create climate resilience in riparian areas }\end{array}$ & \\
\hline
\end{tabular}




\section{Discussion}

Similar to trends identified for the greater western United States, climate change will affect forests of the Rogue Basin in a number of ways, but fire and drought will likely be the key agents of change. Fire suppression and land management have resulted in increased forest density and risk of high-severity wildfire [32,34,35]. A recent study [80] estimated that 1.0 to 1.7 million forested hectares $(57 \%)$ in southwestern Oregon are in need of thinning or prescribed fire to move towards natural range of variability in forest structure. Increased drought with climate change will likely stress high-density forests, increasing their vulnerability to insects and disease, and exacerbating risks of high severity fire [46]. Interactions among these multiple stressors may result in rapid change in forest ecosystem composition and structure, and the ecosystem services provided [11].

Decreasing forest density through thinning and prescribed fire can both reduce the risk of high-severity fire [81-83], and mitigate the effects of drought [6]. Using thinning and prescribed fire to reduce risk of high-severity fire was a clear focus of adaptation actions developed by resource managers in our workshop, as it has been in other similar efforts [84]. While it may be feasible to reduce effects of drought and fire at the stand or project level, and treatments can be prioritized in climate change refugia [85] and / or the most vulnerable portions of the landscape, the spatial scale of treatments would need to be increased considerably, and maintained over time, to function effectively at a large spatial scale. Increasing the scale of treatments would require increased budgets. It would also require increasing public acceptance of active management, including use of prescribed fire, which may come with increased understanding of the connections between ecological and social dynamics, and addressing the concerns of fire-prone communities regarding management of federal lands [86]. In the case of the Rogue Basin, strong social networks and collaborative groups, such as SOFRC, formed of public, scientists, and managers, help foster communication, engagement, and crucial momentum for forest restoration and climate adaptation.

Carbon sequestration and wildlife habitat are also important considerations in determining the scale and placement of treatments. Carbon emissions from mechanical treatments and prescribed fire are significant, but these treatments can reduce subsequent fire severity, potentially reducing impacts on soil and wildlife habitat, and reducing carbon emissions in subsequent wildfires [87-90]. There are uncertainties associated with the long-term effects of thinning and fuel treatment regimes on carbon storage in a changing climate, and further research is needed to evaluate potential short-term and long-term costs and benefits. Managers will have to consider multiple values, ecosystem services, and ecosystem stressors (e.g., fire, insects and disease, and invasive species) in determining treatment type, scale, and intensity with climate change.

Nearly all federal natural resource management agencies have a general response strategy for adaptation to climate change, and some have frameworks for doing so. However, with few previous examples of adaptive management for climate change, and little funding with climate change as a project objective, translating executive orders and overarching strategies for climate adaptation to on-the-ground projects has been difficult. Implementation of adaptation options has been slower than expected due to a number of factors. Field units are encouraged, and in some case required, to consider climate change in planning and management (e.g., [91]), but the generalized nature of this directive in the context of other policy mandates, combined with insufficient budgets and a relatively weak level of accountability, has impeded progress.

Although executive actions, such as the Obama Administration's series of executive orders [16,17], have the force of law, they have less durability than direct legislative mandates that guide resource management on federal lands [92]. There have been several administrations since the first report of the United Nations Intergovernmental Panel on Climate Change, each with unique perceptions and policies regarding the need to mitigate and/or adapt to climate change. In an unstable and unpredictable policy environment, federal land managers may be reluctant to take actions overtly driven by climate change considerations, especially if these actions might have adverse effects on resource production or other environmental values for which there are other policies and established constituencies. 
The means by which climate-informed resource objectives might be accomplished are still being developed and fine-tuned by the science and management communities. Recently, there has been a shift in the overarching goal of federal land management from sustaining certain resources or historical ecological conditions to strengthening resiliency of managed ecosystems to a broader range of future environmental changes, including some that are outside the "historical range of variation" [93-95]. There is an implicit recognition that the location and association of certain plant or animal species, and often entire ecological communities, are likely to shift over time in response to climatic changes in current habitat zones [96,97]. Development of actions to prepare for and adapt to these changing environmental conditions is still in early stages and will take time to mature. For example, scientific uncertainty exists over management actions such as "assisted migration," which is intended to anticipate projected climate changes by introducing species better suited to the expected future climatic conditions $[98,99]$. Although planting of species from areas that currently exhibit the climate conditions projected for the new location is used for some commercial forest plantations [100], skepticism remains about the long-term effects of this approach in complex natural systems [101]. Actions that have a desired effect on ecosystem resiliency in a given location may have different effects in other locations, particularly those near ecotones [102].

Maintaining the status quo is often prevalent in a decision-making environment characterized by uncertainty $[103,104]$. Reduced scientific certainty about effective climate change adaptation options, and consistent policy about climate change adaptation will improve, but not ensure, implementation of vulnerability assessments and adaptation plans. Increasing the knowledge base on climate change effects and tools for implementing adaptation actions on the ground will strengthen confidence about taking actions that may depart from a previous course of action. Our approach involving education, tools, and facilitated process to develop adaptation options for specific projects, can provide confidence for making adaptive shifts in management under a changing climate; particularly when supported by a strong collaborative dynamic.

\section{Conclusions}

By bringing together diverse local participants in a science-management partnership and presenting information on climate change vulnerabilities in the region in a range of formats, we improved understanding of the potential effects of climate change in the Rogue Basin, and enabled evaluation of proposed federal management activities in the context of climatic stressors. Multiple educational tools were utilized, including webinars, a workshop, and a field trip, allowing us to reach more individuals (over 200 in all). But the learning process was not unidirectional; in addition to managers learning about climate science and potential impacts, scientists learned about local effects, management context and constraints, and application of science to a specific project, thereby propagating adaptation through a co-production of knowledge [105]. The Climate Project Screening Tool [42] was effective in facilitating the shared learning process. Finally, by engaging local managers throughout the project, we increased ownership of the process and outcomes, as well as the applicability of the adaptation options to on-the-ground actions.

The Applegate AMA project team members intend to use the information from the workshop to help inform the development of project activities. Not including private landowners and a broader stakeholder group was a limitation of our approach, and a next step will be to include private landowners, local organizations, and the public to further develop a collaborative proposal for management actions in the AMA, account for the potential effects of project activities on ecosystem services, and develop support for project activities. Many of the proposed changes in vegetation management developed by resource managers in the workshop will provide opportunities to implement adaptive management, where feedback from monitoring provides direction for future management (Figure 3). Monitoring the effectiveness of treatments in the Applegate AMA and similar projects will be critical to refine effective adaptation strategies and improve ongoing planning at regional scales. 
In some ways, climate change adaptation in vegetation management is a long-term management experiment. Given that there is no direct historical analog for many of the conditions and circumstances that forest managers have encountered and will continue to discover, uncertainties will continue to exist, even as our knowledge base evolves. Socioeconomic and ecological effects of changing climates will become more evident, but vulnerability assessments and timely implementation of adaptation plans will increasingly be essential to ensuring sustainable management of forests for a range of economic goods and ecosystem services. As has been shown in this case in southwestern Oregon, and in several other locations in the western United States [106], science-management-public partnerships [107] can effectively incorporate evolving science and enable timely progress in adaptation to climate change.

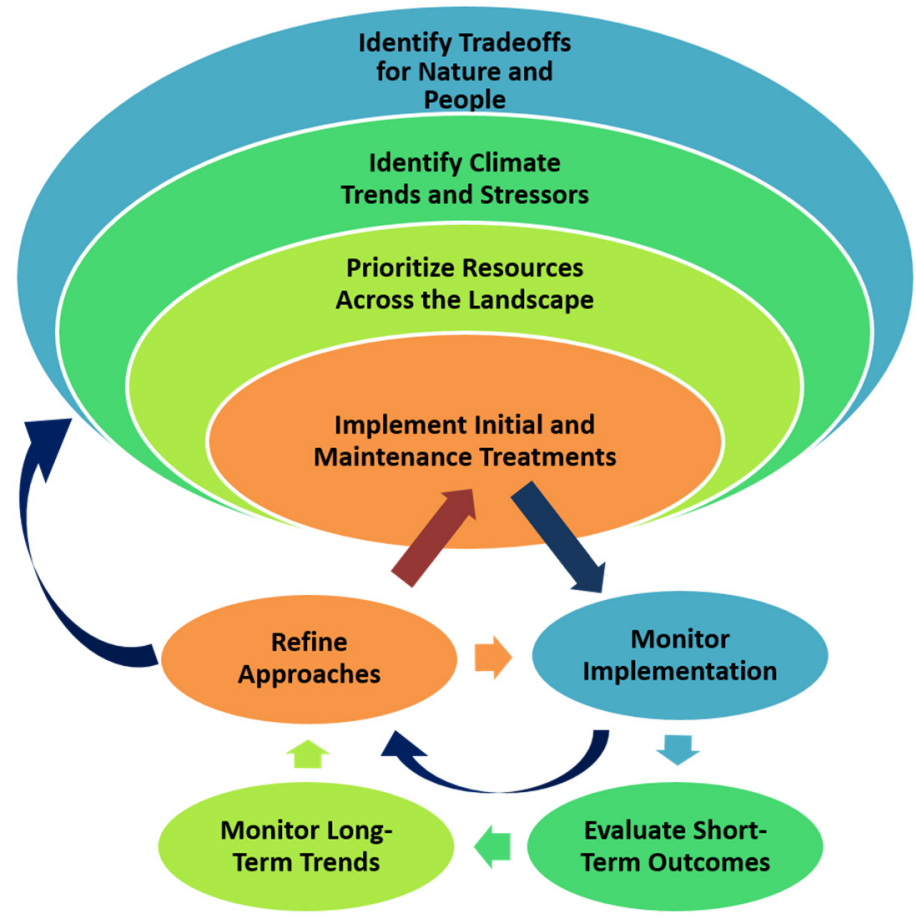

Figure 3. Adaptive management in a changing climate is nested and iterative, involving analysis, implementation, and monitoring to conduct initial work and to refine future and ongoing work. Our vulnerability assessment and workshop process help managers identify climate trends and stressors and prioritize resources across the landscape, which will ultimately feed into all levels of the adaptive management process. In the productive forests of southwestern Oregon the initial entry is the most costly, but ongoing maintenance treatments, preferably with managed fire, are needed to maintain a resilient landscape.

Acknowledgments: This project was funded by the U.S. Department of the Interior, North Pacific Landscape Conservation Cooperative, the Wildlife Conservation Society, and the U.S. Forest Service Pacific Northwest Research Station. We thank the many engaged participants in the webinars and workshops, and appreciate the thoughtful review by Darren Borgias. The Table Rocks climate adaptation demonstration project was a success because of highly engaged partners, including Lomakatsi Restoration Project, Wildlife Conservation Society, Klamath Bird Observatory, TNC, Medford District Bureau of Land Management, U.S. Fish and Wildlife Service, and Natural Resources Conservation Service.

Author Contributions: J.H., D.P., K.M., and M.M. conceived and designed the climate change adaptation partnerships. J.H., D.P., K.M., M.M., and V.S. developed inferences from the assessment and adaptation results, and shared in writing the paper.

Conflicts of Interest: The authors declare no conflict of interest. 


\section{References}

1. Kunkel, K.E.; Palecki, M.A.; Ensor, L.; Easterling, D.; Hubbard, K.G.; Robinson, D.; Redmond, K. Trends in twentieth-century US extreme snowfall seasons. J. Clim. 2009, 22, 6204-6216. [CrossRef]

2. Mote, P.W. Climate-driven variability and trends in Mountain Snowpack in Western North America. J. Clim. 2006, 19, 6209-6220. [CrossRef]

3. Luce, C.H.; Abatzoglou, J.T.; Holden, Z.A. The missing mountain water: Slower westerlies decrease orographic enhancement in the Pacific Northwest USA. Science 2013, 342, 1360-1364. [CrossRef]

4. Luce, C.; Holden, Z. Declining annual streamflow distributions in the Pacific Northwest United States, 1948-2006. Geophys. Res. Lett. 2009, 36, L16401. [CrossRef]

5. Andreadis, K.M.; Lettenmaier, D.P. Trends in 20th century drought over the continental United States. Geophys. Res. Lett. 2006, 33, L10403. [CrossRef]

6. Clark, J.S.; Iverson, L.; Woodall, C.W.; Allen, C.D.; Bell, D.M.; Bragg, D.C.; D'Amato, A.W.; Davis, F.W.; Hersh, M.H.; Ibanez, I.; et al. The impacts of increasing drought on forest dynamics, structure, and biodiversity in the United States. Glob. Chang. Biol. 2016, 22, 2329-2352. [CrossRef]

7. Meddens, A.J.; Hicke, J.A.; Ferguson, C.A. Spatiotemporal patterns of observed bark beetle-caused tree mortality in British Columbia and the western United States. Ecol. Appl. 2012, 22, 1876-1891. [CrossRef]

8. Shaw, J.D.; Steed, B.E.; DeBlander, L.T. Forest inventory and analysis (FIA) annual inventory answers the question: What is happening to pinyon-juniper woodlands? J. For. 2005, 103, 280-285.

9. Westerling, A.L.; Hidalgo, H.G.; Cayan, D.R.; Swetnam, T.W. Warming and earlier spring increase western U.S. forest wildfire activity. Science 2006, 313, 940-943. [CrossRef]

10. Peterson, D.L.; Vose, J.M.; Patel-Weynand, T. (Eds.) Climate Change and United States Forests; Springer: Dordrecht, The Netherlands, 2013.

11. Millar, C.I.; Stephenson, N.L. Temperate forest health in an era of emerging megadisturbance. Science 2015, 349, 823-826. [CrossRef]

12. Noble, I.R.; Huq, S.; Anokhin, Y.A.; Carmin, J.; Goudou, D.; Lansigan, F.P.; Osman-Elasha, B.; Villamizar, A. Adaptation needs and options. In Climate Change 2014: Impacts, Adaptation, and Vulnerability. Part A: Global and Sectoral Aspects. Contribution of Working Group II to the Fifth Assessment Report of the Intergovernmental Panel on Climate Change; Field, C.B., Barros, V.R., Dokken, D.J., Mach, K.J., Mastrandrea, M.D., Bilir, T.E., Chatterjee, M., Ebi, K.L., Estrada, Y.O., Genova, R.C., et al., Eds.; Cambridge University Press: Cambridge, UK; New York, NY, USA, 2014; pp. 833-868.

13. Bierbaum, R.; Smith, J.B.; Lee, A.; Blair, M.; Carter, L.; Chapin, F.S., III; Fleming, P.; Ruffo, S.; Stults, M.; McNeeley, S.; Wasley, E.; Verduzco, L. A comprehensive review of climate adaptation in the United States: More than before, but less than needed. Mitig. Adapt. Strateg. Glob. Chang. 2013, 18, 361-406. [CrossRef]

14. Halofsky, J.E.; Peterson, D.L.; Marcinkowski, K.W. Climate Change Adaptation in United States Federal Natural Resource Science and Management Agencies: A Synthesis; U.S. Global Change Research Program: Washington, DC, USA, 2015. Available online: http://www.globalchange.gov/browse/reports/climatechange-adaptation-united-states-federal-natural-resource-science-and (accessed on 30 August 2016).

15. Millar, C.I.; Swanston, C.W.; Peterson, D.L. Adapting to climate change. In Climate Change and United States Forests; Peterson, D.L., Vose, J.M., Patel-Weynand, T., Eds.; Springer: Dordrecht, The Netherlands, 2014; pp. 183-222.

16. Obama, B. Executive Order 13514 - Federal Leadership in Environmental, Energy, and Economic Performance; United States Government Printing Office: Washington, DC, USA, 2009. Available online: http://www.gpo. gov/fdsys/pkg/DCPD-200900783/pdf/DCPD-200900783.pdf (accessed on 30 August 2016).

17. Obama, B. Executive Order 1365-Preparing the United States for the Impacts of Climate Change; The White House, Office of the Press Secretary: Washington, DC, USA, 2013. Available online: http:/ /www.whitehouse.gov/ the-press-office/2013/11/01/executive-order-preparing-united-states-impacts-climate-change (accessed on 30 August 2016).

18. Cross, M.S.; McCarthy, P.D.; Garfin, G.; Gori, D.; Enquist, C.A. Accelerating adaptation of natural resource management to address climate change. Conserv. Biol. 2013, 27, 4-13. [CrossRef] 
19. Halofsky, J.E.; Peterson, D.L.; Joyce, L.A.; Millar, C.I.; Rice, J.M.; Swanston, C.W. Implementing climate change adaptation in forested regions of the United States. In Forest Conservation and Management in the Anthropocene: Conference Proceedings, Proceedings RMRS-P-71; Sample, V.A., Bixler, R.P., Eds.; U.S. Department of Agriculture, Forest Service, Rocky Mountain Research Station: Fort Collins, CO, USA, 2014; pp. $229-243$.

20. Littell, J.S.; Peterson, D.L.; Millar, C.I.; O'Halloran, K. U.S. National Forests adapt to climate change through science-management partnerships. Clim. Chang. 2012, 110, 269-296. [CrossRef]

21. Peterson, D.L.; Millar, C.I.; Joyce, L.A.; Furniss, M.J.; Halofsky, J.E.; Neilson, R.P.; Morelli, T.L. Responding to Climate Change on National Forests: A Guidebook for Developing Adaptation Options; General Technical Report PNW-GTR-855; U.S. Department of Agriculture, Forest Service, Pacific Northwest Research Station: Portland, OR, USA, 2011.

22. Brandt, L.; He, H.; Iverson, L.; Thompson, F.R.; Butler, P.; Handler, S.; Janowiak, M.; Shannon, P.D.; Swanston, C.; Albrecht, M.; et al. Central Hardwoods Ecosystem Vulnerability Assessment and Synthesis: A Report from the Central Hardwoods Climate Change Response Framework Project; General Technical Report NRS-124; U.S. Department of Agriculture, Forest Service, Northern Research Station: Newtown Square, PA, USA, 2014.

23. Perry, D.A.; Hessburg, P.F.; Skinner, C.N.; Spies, T.A.; Stephens, S.L.; Taylor, A.H.; Franklin, J.F.; McComb, B.; Riegel, G. The ecology of mixed severity fire regimes in Washington, Oregon, and Northern California. For. Ecol. Manag. 2011, 262, 703-717. [CrossRef]

24. Wagner, D.H. Klamath-Siskiyou region, California and Oregon, USA. In Centres of Plant Diversity; Davis, S.D., Heywood, V.H., Herrera-MacBryde, O., Villa-Lobos, J., Hamilton, A.C., Eds.; World Wildlife Fund for Nature and World Conservation Union, Information Press: Oxford, UK, 1997; Volume 3, pp. 74-76.

25. Halofsky, J.E.; Donato, D.C.; Hibbs, D.E.; Campbell, J.L.; Cannon, M.D.; Fontaine, J.B.; Thompson, J.R.; Anthony, R.G.; Bormann, B.T.; Kayes, L.J.; et al. Mixed-severity fire regimes: Lessons and hypotheses from the Klamath-Siskiyou Ecoregion. Ecosphere 2011, 2, 1-19. [CrossRef]

26. Taylor, A.H.; Skinner, C.N. Fire history and landscape dynamics in a late-successional reserve, Klamath Mountains, California, USA. For. Ecol. Manag. 1998, 111, 285-301. [CrossRef]

27. Taylor, A.H.; Skinner, C.N. Spatial patterns and controls on historical fire regimes and forest structure in the Klamath Mountains. Ecol. Appl. 2003, 13, 704-719. [CrossRef]

28. Hoekstra, J.M.; Boucher, T.M.; Ricketts, T.H.; Roberts, C. Confronting a biome crisis: Global disparities of habitat loss and protection. Ecol. Lett. 2005, 8, 23-29. [CrossRef]

29. Agee, J.K. Fire history along an elevational gradient in the Siskiyou Mountains, Oregon. Northwest Sci. 1991, 65, 188-199.

30. Colombaroli, D.; Gavin, D.G. Highly episodic fire and erosion regime over the past 2,000 y in the Siskiyou Mountains, Oregon. Proc. Natl. Acad. Sci. USA 2010, 107, 18909-18914. [CrossRef]

31. McNeil, R.C.; Zobel, D.B. Vegetation and fire history of a ponderosa pine-white fir forest in Crater Lake National Park. Northwest Sci. 1980, 54, 30-46.

32. Sensenig, T.; Bailey, J.D.; Tappeiner, J.C. Stand development, fire and growth of old-growth and young forests in southwestern Oregon, USA. For. Ecol. Manag. 2013, 291, 96-109. [CrossRef]

33. Messier, M.S.; Shatford, J.; Hibbs, D.E. Fire exclusion effects on riparian forest dynamics in southwestern Oregon. For. Ecol. Manag. 2012, 264, 60-71. [CrossRef]

34. Hessburg, P.F.; Churchill, D.J.; Larson, A.J.; Haugo, R.D.; Miller, C.; Spies, T.A.; North, M.P.; Povak, N.A.; Belote, R.T.; Singleton, P.H.; et al. Restoring fire-prone Inland Pacific landscapes: Seven core principles. Landsc. Ecol. 2015, 30, 1805-1835. [CrossRef]

35. Hessburg, P.F.; Spies, T.A.; Perry, D.A.; Skinner, C.N.; Taylor, A.H.; Brown, P.M.; Stephens, S.L.; Larson, A.J.; Churchill, D.J.; Povak, N.A.; et al. Tamm review: Management of mixed-severity fire regime forests in Oregon, Washington, and Northern California. For. Ecol. Manag. 2016, 366, 221-250. [CrossRef]

36. Stephens, S.L.; Agee, J.K.; Fule, P.Z.; North, M.P.; Romme, W.H.; Swetnam, T.W.; Turner, M.G. Managing forests and fire in changing climates. Science 2013, 342, 41-42. [CrossRef]

37. Myer, G. The Rogue Basin Action Plan for Resilient Watersheds and Forests in a Changing Climate; Thaler, T., Griffith, G., Perry, A., Crossett, T., Rasker, R., Eds.; Model Forest Policy Program: Sagle, ID, USA, 2013.

38. Buttrick, S.; Popper, K.; Schindel, M.; McRae, B.; Unnasch, B.; Jones, A.; Platt, J. Conserving Nature's Stage: Identifying Resilient Terrestrial Landscapes in the Pacific Northwest; The Nature Conservancy: Portland, OR, USA, 2015. 
39. Anderson, M.G.; Ferree, C.E. Conserving the stage: Climate change and the geophysical underpinnings of species diversity. PLoS ONE 2010, 5, e11554. [CrossRef]

40. Walsh, J.; Wuebbles, D.; Hayhoe, K.; Kossin, J.; Kunkel, K.; Stephens, G.; Thorne, P.; Vose, R.; Wehner, M.; Willis, J.; et al. Ch. 2: Our changing climate. In Climate Change Impacts in the United States: The Third National Climate Assessment; Melillo, J.M., Richmond, T.C., Yohe, G.W., Eds.; U.S. Global Change Research Program: Washington, DC, USA, 2014; pp. 19-67.

41. Metlen, K.L.; Borgias, D.; Kellogg, B.; Schindel, M.; Jones, A.; McKinley, G.; Olson, D.; Reilly, E.; Moody, B.; Zanger, C. Rogue Basin Cohesive Forest Restoration Strategy: A Collaborative Vision for Resilient Landscapes and Fire Adapted Communities; The Nature Conservancy: Portland, OR, USA, 2015. Available online: http://sofrc.org/2015/08/the-rogue-basin-cohesive-forest-restoration-strategy/ (accessed on 30 August 2016).

42. Morelli, T.L.; Yeh, S.; Smith, N.; Hennessy, M.B.; Millar, C.I. Climate Project Screening Tool: An Aid for Climate Change Adaptation; Research Paper PSW-RP-263; U.S. Department of Agriculture, Forest Service, Pacific Southwest Research Station: Albany, CA, USA, 2012.

43. Schindel, M.; Scott, S.; Jones, A. Rogue Basin Oak Mapping and Climate Resilience: Final Report to the Medford District of the Bureau of Land Management in Partial Fulfillment of Cooperative Agreement L11AC20249; The Oregon Chapter of The Nature Conservancy: Portland, OR, USA, 2013.

44. Millar, C.I.; Stephenson, N.L.; Stephens, S.L. Climate change and forests of the future: managing in the face of uncertainty. Ecol. Appl. 2007, 17, 2145-2151. [CrossRef]

45. Littell, J.S.; Hicke, J.A.; Shafer, S.L.; Capalbo, S.M.; Houston, L.L.; Glick, P. Forests ecosystems: Vegetation, disturbance, and economics. In Climate Change in the Northwest: Implications for Our Landscapes, Waters, and Communities; Dalton, M.M., Mote, P.W., Snover, A., Eds.; Island Press: Washington, DC, USA, 2013; pp. 110-148.

46. Littell, J.S.; Peterson, D.L.; Riley, K.L.; Liu, Y.; Luce, C.H. A review of the relationships between drought and forest fire in the United States. Glob. Chang. Biol. 2016, 22, 2353-2369. [CrossRef]

47. Mote, P.W.; Salathé, E.P. Future climate in the Pacific Northwest. Clim. Chang. 2010, 102, 29-50. [CrossRef]

48. Raymondi, R.R.; Cuhaciyan, J.E.; Glick, P.; Capalbo, S.M.; Houston, L.L.; Shafer, S.L.; Grah, O. Water resources: Implications of changes in temperature and precipitation. In Climate Change in the Northwest: Implications for Our Landscapes, Waters, and Communities; Dalton, M.M., Mote, P.W., Snover, A., Eds.; Island Press: Washington, DC, USA, 2013; pp. 41-58.

49. Mantua, N.; Tohver, I.; Hamlet, A. Climate change impacts on streamflow extremes and summertime stream temperature and their possible consequences for freshwater salmon habitat in Washington State. Clim. Chang. 2010, 102, 187-223. [CrossRef]

50. Rogers, B.M.; Neilson, R.P.; Drapek, R.; Lenihan, J.M.; Wells, J.R.; Bachelet, D.; Law, B.E. Impacts of climate change on fire regimes and carbon stocks of the U.S. Pacific Northwest. J. Geophys. Res.-Biogeosci. 2011, 116, G03037. [CrossRef]

51. Barbero, R.; Abatzoglou, J.; Larkin, N.; Kolden, C.; Stocks, B. Climate change presents increased potential for very large fires in the contiguous United States. Int. J. Wildland Fire 2015, 10, 892-899. [CrossRef]

52. Briles, C.; Whitlock, C.; Skinner, C.; Mohr, J. Holocene forest development and maintenance on different substrates in the Klamath Mountains, northern California, USA. Ecology 2011, 92, 590-601. [CrossRef]

53. Damschen, E.I.; Harrison, S.; Grace, J.B. Climate change effects on an endemic-rich edaphic flora: Resurveying Robert H. Whittaker's Siskiyou sites (Oregon, USA). Ecology 2010, 91, 3609-3619. [CrossRef]

54. Harrison, S.; Damschen, E.; Grace, J. Ecological contingency in the effects of climatic warming on forest herb communities. Proc. Natl. Acad. Sci. USA 2010, 107, 19362-19367. [CrossRef]

55. Rehfeldt, G.E.; Crookston, N.L.; Warwell, M.V.; Evans, J.S. Empirical analyses of plant-climate relationships for the western United States. Int. J. Plant Sci. 2006, 167, 1123-1150. [CrossRef]

56. Lenihan, J.M.; Bachelet, D.; Neilson, R.P.; Drapek, R. Response of vegetation distribution, ecosystem productivity, and fire to climate change scenarios for California. Clim. Chang. 2008, 87, 215-230. [CrossRef]

57. Lenihan, J.M.; Drapek, R.; Bachelet, D.; Neilson, R.P. Climate change effects on vegetation distribution, carbon, and fire in California. Ecol. Appl. 2003, 13, 1667-1681. [CrossRef]

58. Bachelet, D.; Johnson, B.R.; Bridgham, S.D.; Dunn, P.V.; Anderson, H.E.; Rogers, B.M. Climate change impacts on Western Pacific Northwest prairies and savannas. Northwest Sci. 2011, 85, 411-429. [CrossRef] 
59. Pellatt, M.; Gedalof, Z. Environmental change in Garry oak (Quercus garryana) ecosystems: The evolution of an eco-cultural landscape. Biodivers. Conserv. 2014, 23, 2053-2067. [CrossRef]

60. D'Antonio, C.; Vitousek, P.M. Biological invasions by exotic grasses, the grass / fire cycle, and global change. Annu. Rev. Ecol. Syst. 1992, 23, 63-87. [CrossRef]

61. Restaino, C.M.; Peterson, D.L.; Littell, J. Increased water deficit decreases Douglas fir growth throughout western US forests. Proc. Natl. Acad. Sci. USA 2016, 113, 9557-9562. [CrossRef]

62. Allen, C.D.; Breshears, D.D.; McDowell, N.G. On underestimation of global vulnerability to tree mortality and forest die-off from hotter drought in the Anthropocene. Ecosphere 2015, 6, 129. [CrossRef]

63. Brown, T.J.; Hall, B.L.; Westerling, A.L. The impact of twenty-first century climate change on wildland fire danger in the western United States: An applications perspective. Clim. Chang. 2004, 62, 365-388. [CrossRef]

64. Van Mantgem, P.J.; Nesmith, J.C.; Keifer, M.; Knapp, E.E.; Flint, A.; Flint, L. Climatic stress increases forest fire severity across the western United States. Ecol. Lett. 2013, 16, 1151-1156. [CrossRef]

65. Fried, J.S.; Torn, M.S.; Mills, E. The impact of climate change on wildfire severity: A regional forecast for northern California. Clim. Chang. 2004, 64, 169-191. [CrossRef]

66. Campbell, J.; Donato, D.; Azuma, D.; Law, B. Pyrogenic carbon emission from a large wildfire in Oregon, United States. J. Geophys. Res.-Biogeosci. 2007, 112, G04014. [CrossRef]

67. Meigs, G.W.; Donato, D.C.; Campbell, J.L.; Martin, J.G.; Law, B.E. Forest fire impacts on carbon uptake, storage, and emission: The role of burn severity in the Eastern Cascades, Oregon. Ecosystems 2009, 12, 1246-1267. [CrossRef]

68. Amiro, B.D.; Barr, A.G.; Barr, J.G.; Black, T.A.; Bracho, R.; Brown, M.; Chen, J.; Clark, K.L.; Davis, K.J.; Desai, A.R.; Dore, S. Ecosystem carbon dioxide fluxes after disturbance in forests of North America. J. Geophys. Res.-Biogeosci. 2010, 115, G00K02. [CrossRef]

69. Nave, L.E.; Vance, E.D.; Swanston, C.W.; Curtis, P.S. Fire effects on temperate forest soil C and N storage. Ecol. Appl. 2011, 21, 1189-1201. [CrossRef]

70. Eskelson, B.N.; Monleon, V.J.; Fried, J.S. A 6 year longitudinal study of post-fire woody carbon dynamics in California's forests. Can. J. For. Res. 2016, 46, 610-620. [CrossRef]

71. Donato, D.C.; Fontaine, J.B.; Campbell, J.L.; Robinson, W.D.; Kauffman, J.B.; Law, B.E. Conifer regeneration in stand-replacement portions of a large mixed-severity wildfire in the Klamath-Siskiyou Mountains. Can. J. For. Res. 2009, 39, 823-838. [CrossRef]

72. Chambers, M.E.; Fornwalt, P.J.; Malone, S.L.; Battaglia, M.A. Patterns of conifer regeneration following high severity wildfire in ponderosa pine-dominated forests of the Colorado Front Range. For. Ecol. Manag. 2016, 378, 57-67. [CrossRef]

73. Thompson, J.R.; Spies, T.A.; Ganio, L.M. Reburn severity in managed and unmanaged vegetation in a large wildfire. Proc. Natl. Acad. Sci. USA 2007, 104, 10743-10748. [CrossRef]

74. Airey Lauvaux, C.; Skinner, C.N.; Taylor, A.H. High severity fire and mixed conifer forest-chaparral dynamics in the southern Cascade Range, USA. For. Ecol. Manag. 2016, 363, 74-85. [CrossRef]

75. Hu, J.; Moore, D.J.P.; Burns, S.P.; Monson, R.K. Longer growing seasons lead to less carbon sequestration by a subalpine forest. Glob. Chang. Biol. 2010, 16, 771-783. [CrossRef]

76. Temperli, C.; Veblen, T.T.; Hart, S.J.; Kulakowski, D.; Tepley, A.J. Interactions among spruce beetle disturbance, climate change and forest dynamics captured by a forest landscape model. Ecosphere 2015, 6, 231. [CrossRef]

77. Roberts, S.D.; Harrington, C.A. Individual tree growth response to variable-density thinning in coastal Pacific Northwest forests. For. Ecol. Manag. 2008, 255, 2771-2781. [CrossRef]

78. Puettmann, K.J.; Coates, K.D.; Messier, C.C. A Critique of Silviculture: Managing for Complexity; Island Press: Washington, DC, USA, 2009.

79. Joyce, L.A.; Blate, G.M.; Littell, J.S.; McNulty, S.G.; Millar, C.I.; Moser, S.C.; Neilson, R.P.; Peterson, D.L. Managing for multiple resources under climate change. Environ. Manag. 2009, 44, 1022-1032. [CrossRef]

80. Haugo, R.; Zanger, C.; DeMeo, T.; Ringo, C.; Shlisky, A.; Blankenship, K.; Simpson, M.; Mellen-McLean, K.; Kertis, J.; Stern, M. A new approach to evaluate forest structure restoration needs across Oregon and Washington, USA. For. Ecol. Manag. 2015, 335, 37-50. [CrossRef]

81. Shive, K.L.; Sieg, C.H.; Fulé, P.Z. Pre-wildfire management treatments interact with fire severity to have lasting effects on post-wildfire vegetation response. For. Ecol. Manag. 2013, 297, 75-83. [CrossRef] 
82. Martinson, E.J.; Omi, P.N. Fuel Treatments and Fire Severity: A metaanalysis; Research Paper RMRS-RP-103WWW; U.S. Department of Agriculture, Forest Service, Rocky Mountain Research Station: Fort Collins, CO, USA, 2013.

83. Safford, H.D.; Stevens, J.T.; Merriam, K.; Meyer, M.D.; Latimer, A.M. Fuel treatment effectiveness in California yellow pine and mixed conifer forests. For. Ecol. Manag. 2012, 274, 17-28. [CrossRef]

84. Halofsky, J.E.; Peterson, D.L. Climate change vulnerabilities and adaptation options for forest vegetation management in the northwestern USA. Atmosphere 2016, 7, 46. [CrossRef]

85. Morelli, T.L.; Daly, C.; Dobrowski, S.Z.; Dulen, D.M.; Ebersole, J.L.; Jackson, S.T.; Lundquist, J.D.; Millar, C.I.; Maher, S.P.; Monahan, W.B.; et al. Managing climate change refugia for climate adaptation. PLoS ONE 2016, 11, e0159909. [CrossRef]

86. Spies, T.A.; White, E.M.; Kline, J.D.; Bailey, J.; Bolte, J.; Platt, E.; Olsen, C.S.; Jacobs, D.; Shindler, B.; Hammer, R. Examining fire-prone forest landscapes as coupled human and natural systems. Ecol. Soc. 2014, 9, 9. [CrossRef]

87. Wiedinmyer, C.; Hurteau, M.D. Prescribed fire as a means of reducing forest carbon emissions in the western United States. Environ. Sci. Technol. 2010, 44, 1926-1932. [CrossRef]

88. Loudermilk, E.L.; Stanton, A.; Scheller, R.M.; Dilts, T.E.; Weisberg, P.J.; Skinner, C.; Yang, J. Effectiveness of fuel treatments for mitigating wildfire risk and sequestering forest carbon: A case study in the Lake Tahoe Basin. For. Ecol. Manag. 2014, 323, 114-125. [CrossRef]

89. Earles, J.M.; North, M.P.; Hurteau, M.D. Wildfire and drought dynamics destabilize carbon stores of fire-suppressed forests. Ecol. Appl. 2014, 24, 732-740. [CrossRef]

90. Hurteau, M.D.; Liang, S.; Martin, K.L.; North, M.P.; Koch, G.W.; Hungate, B.A. Restoring forest structure and process stabilizes forest carbon in wildfire-prone southwestern ponderosa pine forests. Ecol. Appl. 2016, 26, 382-391. [CrossRef]

91. Federal Register. 36 CFR Part 219. RIN 0596-AD02. In National Forest System Land Management Planning, Final Rule and Record of Decision; U.S. Department of Agriculture, Forest Service: Washington, DC, USA, 2012; Volume 77, pp. 21162-21276.

92. Skillen, J. Federal Ecosystem Management: Its Rise, Fall, and Afterlife; University Press of Kansas: Lawrence, KC, USA, 2015.

93. Allen, C.; Gunderson, L. Pathology and failure in the design and implementation of adaptive management. J. Environ. Manag. 2011, 92, 1379-1384. [CrossRef]

94. Folke, C. Resilience: The emergence of a perspective for social-ecological systems analyses. Glob. Environ. Chang. 2006, 16, 253-267. [CrossRef]

95. Holling, C.; Meffe, G. Command and control and the pathology of natural resource management. Conserv. Biol. 1996, 10, 328-337. [CrossRef]

96. Opdam, P.; Wascher, D. Climate change meets habitat fragmentation: Linking landscape and biogeographical scale levels in research and conservation. Biol. Conserv. 2004, 117, 285-297. [CrossRef]

97. Thuiller, W. Patterns and uncertainties of species range shifts under climate change. Glob. Chang. Biol. 2004, 10, 2020-2027. [CrossRef]

98. McLachlan, J.; Hellmann, J.; Schwartz, M. A framework for debate of assisted migration in an era of climate change. Conserv. Biol. 2007, 21, 297-302. [CrossRef]

99. Kareiva, P.; Fuller, E. Beyond resilience: How to better prepare for the profound disruption of the Anthropocene. Glob. Policy 2016, 7, 107-118. [CrossRef]

100. Williams, M.; Dumroese, R.K. Planning the future's forests with assisted migration. In Forest Conservation and Management in the Anthropocene; Sample, V.A., Bixler, R.P., Eds.; USDA Forest Service Rocky Mountain Research Station: Fort Collins, CO, USA, 2014; pp. 133-144.

101. Doak, D.; Bakker, V.; Goldstein, B.; Hale, B. What is the future of conservation? In Protecting the Wild: Parks and Wilderness, the Foundation for Conservation; Wuerthner, G., Crist, E., Butler, T., Eds.; Island Press: Washington, DC, USA, 2015; pp. 27-35.

102. Hampe, A.; Petit, R.J. Conserving biodiversity under climate change: The rear edge matters. Ecol. Lett. 2005, 8, 461-467. [CrossRef]

103. Tversky, A.; Kahneman, D. Judgment under uncertainty: heuristics and biases. Science 1974, 185, $141-162$. [CrossRef] 
104. Maguire, L.A.; Albright, E.A. Can behavioral decision theory explain risk averse fire management decisions? For. Ecol. Manag. 2005, 211, 47-58. [CrossRef]

105. Meadow, A.M.; Ferguson, D.B.; Guido, Z.; Horangic, A.; Owen, G.; Wall, T. Moving toward the deliberate coproduction of climate science knowledge. Weather Clim. Soc. 2015, 7, 179-191. [CrossRef]

106. Sample, A.; Halofsky, J.E.; Peterson, D.L. U.S. strategy for forest management adaptation to climate change: Building a framework for decision making. Ann. For. Sci. 2014, 71, 125-130. [CrossRef]

107. Golladay, S.; Martin, K.; Vose, J.; Wear, D.; Covich, A.; Hobbs, R.; Klepzig, K.; Likens, G.; Naiman, R.; Shearer, A. Achievable future conditions as a framework for guiding forest conservation and management. For. Ecol. Manag. 2006, 360, 80-96. [CrossRef]

(C) 2016 by the authors; licensee MDPI, Basel, Switzerland. This article is an open access article distributed under the terms and conditions of the Creative Commons Attribution (CC-BY) license (http://creativecommons.org/licenses/by/4.0/). 